\title{
KINETICS OF SUBSTITUTION OF CIS-BIS(MALONATO)DIAQUOCHROMATE(III) WITH GLYCINE, DL-ALANINE AND DL-PHENYLALANINE IN ALKALINE MEDIUM
}

\author{
Venkata Subba Rao Mushini ${ }^{1 *}$, V. Ananta Ramam ${ }^{2}$ and V. Muralidhara Rao ${ }^{2}$ \\ ${ }^{1}$ Department of Chemistry, G.M.R. Institute of Technology, Rajam 532 127, Andhra Pradesh, \\ India \\ ${ }^{2}$ School of Chemistry, Andhra University, Visakhapatnam 530 003, Andhra Pradesh, India
}

(Received July 20, 2009; revised September 13, 2010)

\begin{abstract}
The kinetics of interaction among amino acids such as glycine, DL-alanine and DL-phenylalanine and cis-bis(malonato)diaquochromate(III) has been studied spectrophotometrically as a function of [glycine], [DL-alanine] and [DL-phenylalanine] in alkaline medium. The effect of $\mathrm{pH}$, temperature and substrate was also studied. The substitution reaction has been found to proceed via two steps: amino acid dependent and amino acid independent path. In this process, it indicated that the substitution reaction occurs through an $\mathrm{I}_{\mathrm{a}}$ mechanism in the amino acid dependent path and a dissociative mechanism in the independent path, showing the higher reactivity of single ended malonate complex.
\end{abstract}

KEY WORDS: Substitution, cis-bis(Malonato)diaquochromate(III), Amino acids, Alkaline medium

\section{INTRODUCTION}

Limited information is available about amino acids as ligands, though the substitution reactions at chromium(III) centers are well studied. Krishnamuthy [1] has reviewed the substitution reactions of the oxalate complexes of chromium(III). However, very few papers have been published on the kinetics of $\operatorname{Cr}\left(\mathrm{C}_{2} \mathrm{O}_{4}\right)_{2} \mathrm{X}_{2}^{\mathrm{n}-}$ moiety; where $\mathrm{X}$ is any monodentate ligand other than water [2-6].

Banerjea and Dutta Chaudhuri [7] identified that the bond formation by glycine takes place simultaneously with the rupture of the $\mathrm{Cr}^{-} \mathrm{OH}_{2}$ bond in the kinetics of reaction of hexaaquochromium(III) with glycine. This reaction is further examined by Khan and Kabir-udDin [8]. They suggested an associative interchange mechanism with a kinetic evidence for the formation of ion pair. The reaction between glycine and chromium(III) results in the formation of the tetra aquaglycinato chromium(III) complex [9] in the $\mathrm{pH}$ range of 3.0 to 3.8 . While taking the anation study of mono(oxalato)tetraquochromium(III) with glycine, Subrahmanyam and Ananta Ramam [10] suggested a glycine dependent path representing an associative interchange $\left(\mathrm{I}_{\mathrm{a}}\right)$ mechanism and glycine independent path representing a dissociative inter-change $\left(\mathrm{I}_{\mathrm{d}}\right)$ mechanism. A dissociative mechanism is proposed by Ramasami [11] in the kinetics of the $\mathrm{Cr}\left(\mathrm{NH}_{3}\right)_{5} \mathrm{H}_{2} \mathrm{O}^{3+}$ - glycine reaction, where $\mathrm{Cr}^{-} \mathrm{OH}_{2}$ bond breaking is a dominant factor in this investigation.

In the kinetics of substitution of aquo ligand from hydroxopentaaquochromium(III) by DLalanine, Niogy and De [12] noticed that the rate of anation by alanine is much faster than that of isotopic water exchange and other anation processes. They also studied the anation reaction [13] with DL-phenylalanine. Mitra and De $[14,15]$ proposed an $I_{a}$ mechanism in the kinetics of anation reaction of cis-diaquo-bis-oxalatochromate(III) ion by DL-alanine and DLphenylalanine by observing the significance of both bond breaking and bond making.

Several workers [16-23] have reported the kinetic reactions of hexaaquochromium(III) with different amino acids. Subba Rao et al. [24, 25] suggested the amino acid dependent and amino

*Corresponding author. E-mail: srmushini@rediffmail.com 
acid independent paths in the reactions of kinetics of substitution of cisbis(malonato)diaquochromate(III) and cis-bis(oxalato)diaquochromate(III) with amino acids such as glycine, DL-alanine and DL-phenylalanine in acid medium. Based on the available reported literature, the results relating to the formation of chromium(III)-amino acid complex from cis-bis(malonato)diaquochromate(III) and amino acids in alkaline medium are reported in the present communication.

\section{EXPERIMENTAL}

The potassium salt of cis-bis(malonato)diaquochromate(III) was prepared by a reported [26] method, and its purity was confirmed by analysis [27]. The complex was analysed for chromium and malonate. Chromium was determined by oxidizing chromium(III) to chromium(VI) with alkaline $\mathrm{H}_{2} \mathrm{O}_{2}$ and titrating the later with standard $\mathrm{Fe}^{2+}$. Malonate [27] was estimated by extensive oxidation with chromium(VI). $2 \mathrm{~mL}$ of $5.0 \times 10^{-2} \mathrm{M}$ solution of cis-bis(malonato)diaquochromate(III) complex and $10 \mathrm{~mL}$ of $1.0 \mathrm{M}$ sodium hydroxide solution was taken and it was diluted to $50 \mathrm{~mL}$ and heated gently for a few minutes. The chromium hydroxide formed was filtered off and the contents were reduced to $10 \mathrm{~mL}$ by evaporation. To this, $20 \mathrm{~mL}$ of concentrated sulfuric acid and $10 \mathrm{~mL}$ of $0.05 \mathrm{M}$ potassium dichromate were added and heated on a steam bath for two hours. The reaction mixtures were cooled to room temperature and 5 $\mathrm{mL}$ of concentrated phosphoric acid was added and the unreacted chromium(VI) was titrated with standard $\mathrm{Fe}^{2+}$. The chromium to malonate ratio was found to be 2.02 . Other method was also followed to confirm the purity of the synthesized complex. The visible absorption spectrum of the synthesized metal complex showed maxima at $415 \mathrm{~nm}\left(\varepsilon=41.6 \mathrm{M}^{-1} \mathrm{~cm}^{-1}\right)$ and $570 \mathrm{~nm}(\varepsilon$ $\left.=48.8 \mathrm{M}^{-1} \mathrm{~cm}^{-1}\right)$ as against reported [26] maxima at $417 \mathrm{~nm}\left(\varepsilon=41.4 \mathrm{M}^{-1} \mathrm{~cm}^{-1}\right)$ and $566 \mathrm{~nm}(\varepsilon=$ $\left.49.9 \mathrm{M}^{-1} \mathrm{~cm}^{-1}\right)$. All other chemicals used were of reagent grade and all the solutions were prepared with triply distilled water. The products of the reaction between the substrate complex and amino acids were prepared by mixing different molar ratios of reactants viz., 1:1, 1:2 and $1: 3$ at $\mathrm{pH} 8.50$ and thermostating the mixture at $50{ }^{\circ} \mathrm{C}$ for 30 hours. The absorption spectra of the resulting solution were recorded using an aqueous ligand solution of appropriate molarity in the reference cell and it was found that all the three product complexes were identical, having a maximum absorption at 398 and $540 \mathrm{~nm}$. Figure 1 shows the spectral difference between the product and substrate complex.

\section{Kinetic studies}

The progress of the reaction was monitored by the absorbance measurements for the product at different intervals of time with a MILTON ROY Spectronic 1201 UV visible spectrophotometer (USA). Temperature control in these studies was achieved by the use of thermostat with circulating pump attachment, enabling the control of the reaction vessel temperature $\pm 0.1{ }^{\circ} \mathrm{C}$. Measurement of $\mathrm{pH}$ was carried out with a Systronics digital $\mathrm{pH}$ meter (model 335, India) with an accuracy of \pm 0.01 . Sodium hydroxide solution was added to adjust $\mathrm{pH}$. The ionic strength of the reaction medium was adjusted by addition of sodium perchlorate. Required quantities of amino acid (using the stock solutions of $0.25 \mathrm{M}$ of glycine and DL-alanine and 0.1 M of DLphenylalanine) and sodium perchlorate (using 4.0 M stock) solutions were added to a beaker and then $\mathrm{pH}$ was adjusted (to a particular value) and were taken into a stoppered containers and they were thermostated to attain the experimental temperature. The substrate (metal complex) and distilled water were kept at that temperature. A known quantity of the metal complex (from $0.05 \mathrm{M}$ stock) solution was added and contents were diluted to a definite volume with distilled water. Conventional mixing technique was followed and a portion of the reaction mixture was transferred to an optical cell placed in the cell compartment of the spectrophotometer. The rate 
of the reaction was monitored by measuring the absorbance at $530 \mathrm{~nm}$ and the reaction was followed up to $80-90 \%$ completion. The absorbance reading at infinite time, $\mathrm{A}_{\infty}$ was obtained, keeping the reaction mixture long enough for the reaction to be completed. KINTOB [28, 29] software was used to evaluate the rate constants. The substitution reaction has been studied as a function of the concentration of amino acids, $\mathrm{pH}$ and substrate.

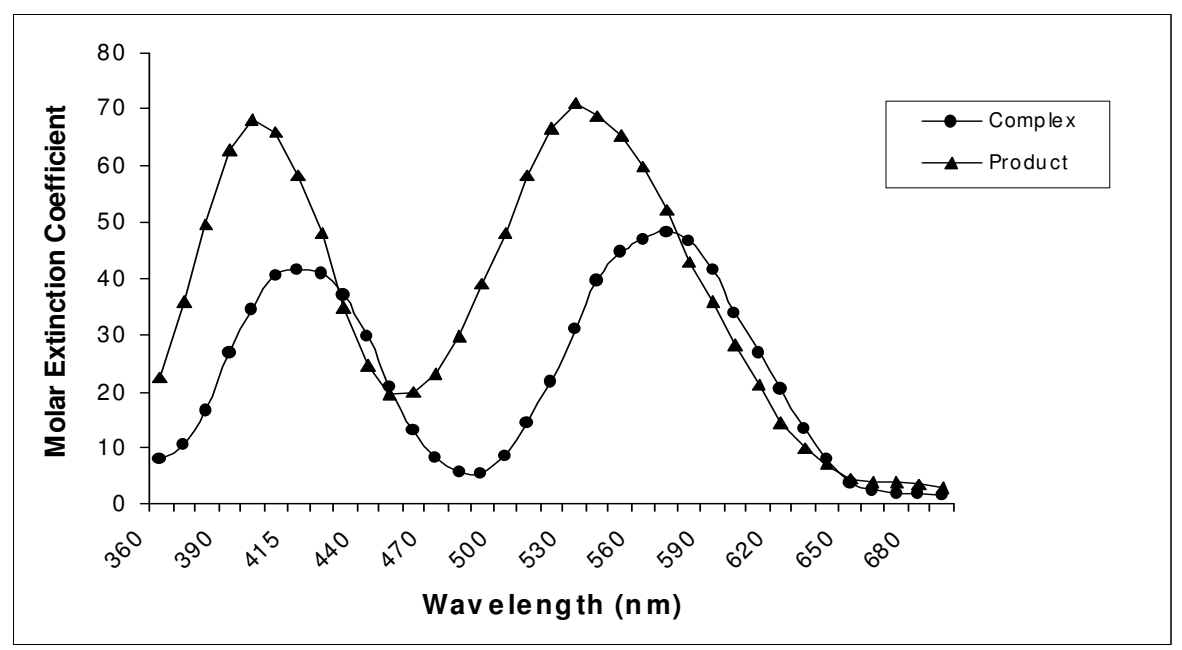

Figure 1. Spectral difference between the complex and the amino acid substituted product. $\left[\mathrm{Cr}(\mathrm{mal})_{2}\left(\mathrm{H}_{2} \mathrm{O}\right)_{2}{ }^{-}\right]=4.00 \times 10^{-3} \mathrm{M},[$ amino acid $]=8.00 \times 10^{-2} \mathrm{M}, \mathrm{pH}=8.50$.

\section{RESULTS AND DISCUSSION}

\section{Effect of concentration of amino acids}

The pseudo-first order rate constants were evaluated from the straight line plot of $\log \left(\mathrm{A}_{\infty}-\mathrm{A}_{\mathrm{t}}\right)$ vs. time by using KINTOB software procedure The rate of the reaction increases with increase in the concentration of amino acids (Table 1). In the amino acid variation studies the $\mathrm{pH}$ was kept constant by the addition of dilute solution of sodium hydroxide. A typical plot of $\mathrm{k}_{\mathrm{obs}} \mathrm{vs}$ [glycine] (Figure 2) is linear with an intercept on the rate axis, suggesting that the reaction proceeds by two paths: amino acid dependent and amino acid independent. The same type of plots was also observed in the case of DL-alanine and DL-phenyl alanine.

\section{Effect of $p H$}

The concentration of substrate and amino acid were kept constant and the $\mathrm{pH}$ was varied. The rate of the reaction increases with increase in $\mathrm{pH}$ (Table 2). The values of pk against $\mathrm{pH}$ are presented in the Table 3. A plot (Figure 3) of pk vs $\mathrm{pH}$ gives a straight line with a slope less than unity indicating the involvement of $\mathrm{H}^{+}$in the equilibrium step. 
Table 1. Variation of rate constants with [glycine], [DL-alanine] and [DL-Phenyl alanine].

\begin{tabular}{|c|c|c|c|c|c|c|c|c|c|c|c|}
\hline \multicolumn{4}{|c|}{$\begin{array}{c}\text { With [glycine] } \\
{\left[\mathrm{Cr}(\mathrm{mal})_{2}\left(\mathrm{H}_{2} \mathrm{O}\right)_{2}\right]=4.0 \times 10^{-3} \mathrm{M}} \\
\mathrm{pH}=8.50, \mu=1.0 \mathrm{M}\end{array}$} & \multicolumn{4}{|c|}{$\begin{array}{c}\text { With [DL-alanine] } \\
{\left[\mathrm{Cr}(\mathrm{mal})_{2}\left(\mathrm{H}_{2} \mathrm{O}\right)_{2}\right]=4.0 \times 10^{-3} \mathrm{M}} \\
\mathrm{pH}=8.50, \mu=1.0 \mathrm{M}\end{array}$} & \multicolumn{4}{|c|}{$\begin{array}{c}\text { With [DL-phenylalanine] } \\
{\left[\mathrm{Cr}(\mathrm{mal})_{2}\left(\mathrm{H}_{2} \mathrm{O}\right)_{2}\right]=2.0 \times 10^{-3} \mathrm{M}} \\
\mathrm{pH}=8.50, \mu=1.0 \mathrm{M}\end{array}$} \\
\hline \multirow{2}{*}{$\begin{array}{c}{[\mathrm{Gly}]} \\
\times 10^{2} \mathrm{M} \\
\end{array}$} & \multicolumn{3}{|c|}{$\mathrm{k}_{\mathrm{obs}} \times 10^{4} \mathrm{~s}^{-1}$} & \multirow{2}{*}{\begin{tabular}{|c|} 
[Ala] \\
$\times 10^{2} \mathrm{M}$ \\
\end{tabular}} & \multicolumn{3}{|c|}{$\mathrm{k}_{\mathrm{obs}} \times 10^{4} \mathrm{~s}^{-1}$} & \multirow{2}{*}{\begin{tabular}{|c|}
{$[\mathrm{Phe}]$} \\
$\times 10^{2} \mathrm{M}$ \\
\end{tabular}} & \multicolumn{3}{|c|}{$\mathrm{k}_{\mathrm{obs}} \times 10^{4} \mathrm{~s}^{-1}$} \\
\hline & $45.0^{\circ} \mathrm{C}$ & $50.0^{\circ} \mathrm{C}$ & $55.0^{\circ} \mathrm{C}$ & & $45.0^{\circ} \mathrm{C}$ & $50.0^{\circ} \mathrm{C}$ & $55.0^{\circ} \mathrm{C}$ & & $45.0^{\circ} \mathrm{C}$ & $50.0^{\circ} \mathrm{C}$ & $55.0^{\circ} \mathrm{C}$ \\
\hline 2.0 & 3.34 & 5.02 & 6.68 & 2.0 & 3.24 & 4.61 & 6.29 & 1.0 & 3.10 & 4.33 & 6.03 \\
\hline 4.0 & 4.06 & 5.81 & 7.58 & 4.0 & 3.75 & 5.42 & 7.18 & 1.5 & 3.31 & 4.61 & 6.32 \\
\hline 6.0 & 4.82 & 6.87 & 9.03 & 6.0 & 4.39 & 6.19 & 8.24 & 2.0 & 3.56 & 4.89 & 6.71 \\
\hline 8.0 & 5.61 & 7.94 & 10.02 & 8.0 & 4.98 & 6.94 & 9.19 & 2.5 & 3.81 & 5.16 & 7.11 \\
\hline 10.0 & 6.39 & 8.98 & 10.71 & 10.0 & 5.51 & 7.69 & 10.33 & 3.0 & 4.11 & 5.42 & 7.43 \\
\hline 12.0 & 7.14 & 10.03 & 11.47 & 12.0 & 6.17 & 8.42 & 11.16 & --- & --- & --- & \\
\hline
\end{tabular}

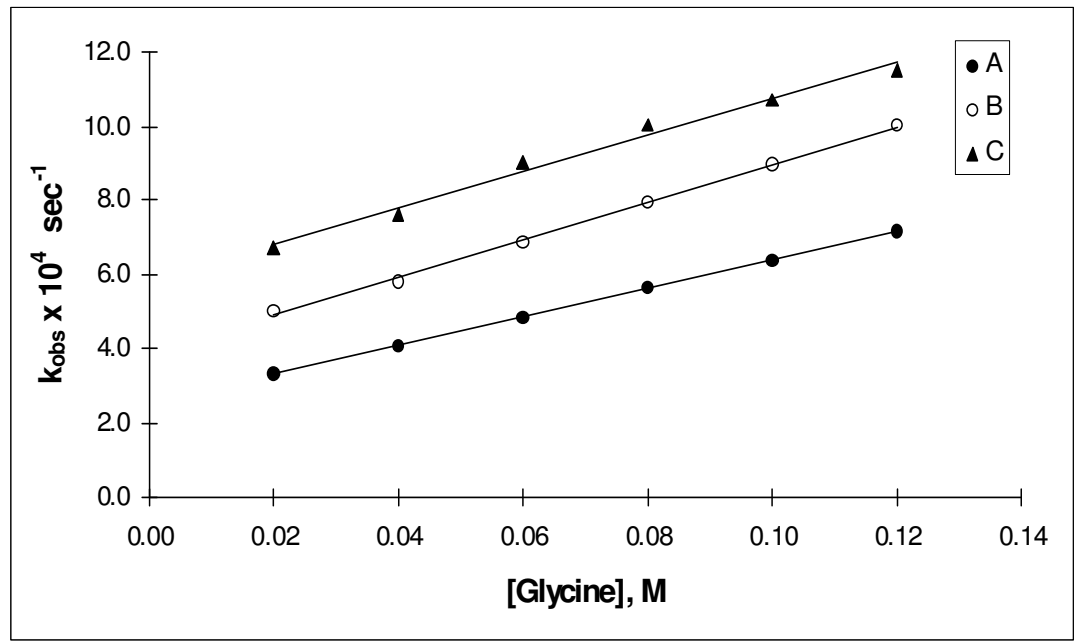

Figure 2. Typical plot of rate constant vs. concentration of glycine: $\mathrm{A}=45.0^{\circ} \mathrm{C}, \mathrm{B}=50.0^{\circ} \mathrm{C}$ and $\mathrm{C}=55.0^{\circ} \mathrm{C} .\left[\mathrm{Cr}(\mathrm{mal})_{2}\left(\mathrm{H}_{2} \mathrm{O}\right)_{2}{ }^{-}\right]=4.00 \times 10^{-3} \mathrm{M}, \mathrm{pH}=8.50$.

Table 2. Variation of rate constants with $\mathrm{pH}$.

\begin{tabular}{|c|c|c|c|c|c|c|c|c|c|c|c|}
\hline \multicolumn{4}{|c|}{$\begin{array}{c}{\left[\mathrm{Cr}(\mathrm{mal})_{2}\left(\mathrm{H}_{2} \mathrm{O}\right)_{2}{ }^{-}\right]=4.0 \times 10^{-3} \mathrm{M}} \\
{[\text { glycine }]=8.0 \times 10^{-2} \mathrm{M}} \\
\mu=1.0 \mathrm{M}\end{array}$} & \multicolumn{4}{|c|}{$\begin{array}{c}{\left[\mathrm{Cr}(\mathrm{mal})_{2}\left(\mathrm{H}_{2} \mathrm{O}\right)_{2}{ }^{-}\right]=4.0 \times 10^{-3} \mathrm{M}} \\
{[\mathrm{DL} \text {-alanine }]=8.0 \times 10^{-2} \mathrm{M}} \\
\mu=1.0 \mathrm{M}\end{array}$} & \multicolumn{4}{|c|}{$\begin{array}{c}{\left[\mathrm{Cr}(\mathrm{mal})_{2}\left(\mathrm{H}_{2} \mathrm{O}\right)_{2}{ }^{-}\right]=2.0 \times 10^{-3} \mathrm{M}} \\
{[\mathrm{DL}-\text { phenylalanine }]=2.0 \times 10^{-2} \mathrm{M}} \\
\mu=1.0 \mathrm{M}\end{array}$} \\
\hline \multirow{2}{*}{$\mathrm{pH}$} & \multicolumn{3}{|c|}{$\mathrm{k}_{\mathrm{obs}} \times 10^{4} \mathrm{~s}^{-1}$} & \multirow{2}{*}{$\mathrm{pH}$} & \multicolumn{3}{|c|}{$\mathrm{k}_{\mathrm{obs}} \times 10^{4} \mathrm{~s}^{-1}$} & \multirow{2}{*}{$\mathrm{pH}$} & \multicolumn{3}{|c|}{$\mathrm{k}_{\mathrm{obs}} \times 10^{4} \mathrm{~s}^{-1}$} \\
\hline & $45.0^{\circ} \mathrm{C}$ & $50.0^{\circ} \mathrm{C}$ & $55.0^{\circ} \mathrm{C}$ & & $45.0^{\circ} \mathrm{C}$ & $50.0^{\circ} \mathrm{C}$ & $55.0^{\circ} \mathrm{C}$ & & $45.0^{\circ} \mathrm{C}$ & $50.0^{\circ} \mathrm{C}$ & $55.0^{\circ} \mathrm{C}$ \\
\hline 7.40 & 3.14 & 4.32 & 6.11 & 7.40 & 2.98 & 4.17 & 5.74 & 7.40 & 2.06 & 2.72 & 3.84 \\
\hline 7.60 & 3.40 & 4.76 & 6.55 & 7.60 & 3.19 & 4.52 & 6.19 & 7.60 & 2.22 & 2.96 & 4.06 \\
\hline 7.80 & 3.87 & 5.38 & 7.27 & 7.80 & 3.42 & 4.84 & 6.65 & 7.80 & 2.44 & 3.31 & 4.41 \\
\hline 8.10 & 4.61 & 6.31 & 8.42 & 8.00 & 3.81 & 5.40 & 7.35 & 8.00 & 2.71 & 3.63 & 5.04 \\
\hline 8.20 & 4.82 & 6.62 & 8.89 & 8.30 & 4.49 & 6.31 & 8.51 & 8.30 & 3.19 & 4.31 & 5.92 \\
\hline 8.40 & 5.31 & 7.46 & 9.42 & 8.50 & 4.98 & 6.94 & 9.19 & 8.50 & 3.56 & 4.89 & 6.71 \\
\hline 8.50 & 5.61 & 7.94 & 10.02 & 8.60 & 5.31 & 7.25 & 9.62 & 8.60 & 3.75 & 5.11 & 7.06 \\
\hline 8.70 & 6.29 & 8.94 & 11.06 & 8.70 & 5.56 & 7.59 & 10.33 & 8.70 & 3.93 & 5.34 & 7.38 \\
\hline
\end{tabular}

Bull. Chem. Soc. Ethiop. 2011, 25(1) 
Table 3. Variation of pk values with $\mathrm{pH}$.

\begin{tabular}{|c|c|c|c|c|c|c|c|c|c|c|c|}
\hline \multicolumn{4}{|c|}{$\begin{array}{c}{\left[\mathrm{Cr}(\mathrm{mal})_{2}\left(\mathrm{H}_{2} \mathrm{O}\right)_{2}{ }^{-}\right]=4.0 \times 10^{-3} \mathrm{M}} \\
{[\text { glycine }]=8.0 \times 10^{-2} \mathrm{M}} \\
\mu=1.0 \mathrm{M}\end{array}$} & \multicolumn{4}{|c|}{$\begin{array}{c}{\left[\mathrm{Cr}(\mathrm{mal})_{2}\left(\mathrm{H}_{2} \mathrm{O}\right)_{2}{ }^{-}\right]=4.0 \times 10^{-3} \mathrm{M}} \\
{[\mathrm{DL} \text {-alanine }]=8.0 \times 10^{-2} \mathrm{M}} \\
\mu=1.0 \mathrm{M}\end{array}$} & \multicolumn{4}{|c|}{$\begin{array}{c}{\left[\mathrm{Cr}(\mathrm{mal})_{2}\left(\mathrm{H}_{2} \mathrm{O}\right)_{2}{ }^{-}\right]=2.0 \times 10^{-3} \mathrm{M}} \\
{[\mathrm{DL}-\text { phenylalanine }]=2.0 \times 10^{-2} \mathrm{M}} \\
\mu=1.0 \mathrm{M}\end{array}$} \\
\hline \multirow{2}{*}{$\mathrm{pH}$} & \multicolumn{3}{|c|}{$\mathrm{pk}$} & \multirow{2}{*}{$\mathrm{pH}$} & \multicolumn{3}{|c|}{$\mathrm{pk}$} & \multirow{2}{*}{$\mathrm{pH}$} & \multicolumn{3}{|c|}{$\mathrm{pk}$} \\
\hline & $45.0^{\circ} \mathrm{C}$ & $50.0^{\circ} \mathrm{C}$ & $55.0^{\circ} \mathrm{C}$ & & $45.0^{\circ} \mathrm{C}$ & $50.0^{\circ} \mathrm{C}$ & $55.0^{\circ} \mathrm{C}$ & & $45.0^{\circ} \mathrm{C}$ & $50.0^{\circ} \mathrm{C}$ & $55.0^{\circ} \mathrm{C}$ \\
\hline 7.40 & 3.50 & 3.36 & 3.21 & 7.40 & 3.53 & 3.38 & 3.24 & 7.40 & 3.69 & 3.57 & 3.42 \\
\hline 7.60 & 3.47 & 3.32 & 3.18 & 7.60 & 3.50 & 3.34 & 3.21 & 7.60 & 3.65 & 3.53 & 3.39 \\
\hline 7.80 & 3.41 & 3.26 & 3.14 & 7.80 & 3.47 & 3.32 & 3.18 & 7.80 & 3.61 & 3.48 & 3.36 \\
\hline 8.10 & 3.34 & 3.20 & 3.08 & 8.00 & 3.42 & 3.27 & 3.13 & 8.00 & 3.57 & 3.44 & 3.30 \\
\hline 8.20 & 3.32 & 3.18 & 3.05 & 8.30 & 3.35 & 3.20 & 3.07 & 8.30 & 3.50 & 3.37 & 3.23 \\
\hline 8.40 & 3.27 & 3.13 & 3.02 & 8.50 & 3.30 & 3.16 & 3.04 & 8.50 & 3.45 & 3.31 & 3.17 \\
\hline 8.50 & 3.25 & 3.10 & 3.00 & 8.60 & 3.27 & 3.14 & 3.02 & 8.60 & 3.43 & 3.29 & 3.15 \\
\hline 8.70 & 3.20 & 3.04 & 2.96 & 8.70 & 3.25 & 3.12 & 2.99 & 8.70 & 3.41 & 3.27 & 3.13 \\
\hline
\end{tabular}

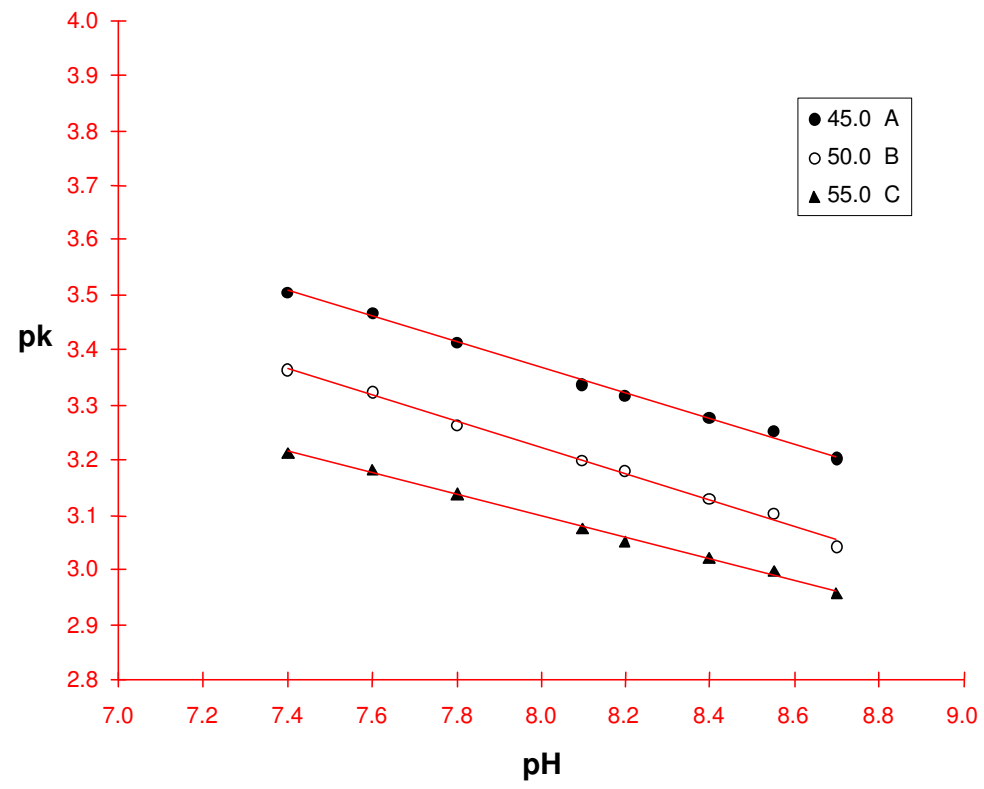

Figure 3. Typical plot of pk vs $\mathrm{pH}$ of glycine: $\mathrm{A}=45.0^{\circ} \mathrm{C}, \mathrm{B}=50.0^{\circ} \mathrm{C}$ and $\mathrm{C}=55.0^{\circ} \mathrm{C}$. $\left[\mathrm{Cr}(\mathrm{mal})_{2}\left(\mathrm{H}_{2} \mathrm{O}\right)_{2}{ }^{-}\right]=4.00 \times 10^{-3} \mathrm{M},[$ glycine $]=8.0 \times 10^{-2} \mathrm{M}$.

\section{Effect of substrate}

In this kinetic study at $\mathrm{pH} 8.50$, keeping the constant concentration of amino acids and varying the concentration of metal complex, the rate constants are evaluated. From it can be observed that the concentration of the substrate does not have any effect on the rate constant, showing thereby the order with respect to substrate is unity.

From these observations and results, the activation parameters are calculated by least square method. The slopes and intercepts (representing the glycine, DL-alanine and DL-phenylalanine dependent and independent paths) of the plots of the rate constant vs [amino acids] are evaluated at three different temperatures $\left(45.0,50.0\right.$ and $\left.55.0^{\circ} \mathrm{C}\right)$. Arrhenius plots of $\log \mathrm{k}$ 
against $1 / \mathrm{T}$ are then drawn. The slopes of the linear plots multiplied by $2.303 \mathrm{R}(\mathrm{R}=8.314 \mathrm{~J}$ $\left.\mathrm{K}^{-1} \mathrm{~mol}^{-1}\right)$ give the activation energies $(\Delta \mathrm{E})$ of the two paths of the reaction. Plots of $\log \left(\mathrm{k}_{\mathrm{h}} / \mathrm{KT}\right)$ against $1 / \mathrm{T}$ are drawn (Eyring plot) and it give a straight line provided the heats of activation $\left(\Delta \mathrm{H}^{\ddagger}\right)$ \{slope multiplied by $\left.2.303 \mathrm{R}\right\}$ and entropies of activation $\left(\Delta \mathrm{S}^{\ddagger}\right)$ intercept multiplied by 2.303R; $\mathrm{R}=8.314 \mathrm{~J} \mathrm{~K}^{-1} \mathrm{~mol}^{-1}$ \}. The values of the activation parameters of the two paths (ligand dependent and ligand independent) of the reaction are presented in Table 4.

Table 4. Activation parameters.

\begin{tabular}{|c|c|c|c|c|c|c|c|c|c|}
\hline & \multicolumn{3}{|c|}{ Glycine } & \multicolumn{3}{c|}{ DL-alanine } & \multicolumn{3}{c|}{ DL-phenylalanine } \\
\cline { 2 - 10 } & $\begin{array}{c}\Delta \mathrm{H}^{\ddagger} \\
\mathrm{kJ} / \mathrm{mol}\end{array}$ & $\begin{array}{c}\Delta \mathrm{E} \\
\mathrm{kJ} / \mathrm{mol}\end{array}$ & $\begin{array}{c}\Delta \mathrm{S}^{\ddagger} \\
\mathrm{kJ} / \mathrm{mol}\end{array}$ & $\begin{array}{c}\Delta \mathrm{H}^{\ddagger} \\
\mathrm{kJ} / \mathrm{mol}\end{array}$ & $\begin{array}{c}\Delta \mathrm{E} \\
\mathrm{kJ} / \mathrm{mol}\end{array}$ & $\begin{array}{c}\Delta \mathrm{S}^{\ddagger} \\
\mathrm{kJ} / \mathrm{mol}\end{array}$ & $\begin{array}{c}\Delta \mathrm{H}^{\ddagger} \\
\mathrm{kJ} / \mathrm{mol}\end{array}$ & $\begin{array}{c}\Delta \mathrm{E} \\
\mathrm{kJ} / \mathrm{mol}\end{array}$ & $\begin{array}{c}\Delta \mathrm{S}^{\ddagger} \\
\mathrm{kJ} / \mathrm{mol}\end{array}$ \\
\hline Amino acid dependent, $\mathrm{k}^{\prime}$ & 55.6 & 59.2 & -117 & 47.4 & 50.5 & -145 & 44.8 & 47.9 & -150 \\
\hline Amino acid independent, $\mathrm{k}^{\prime \prime}$ & 70.7 & 74.1 & -91.5 & 68.0 & 71.1 & -101 & 68.0 & 71.0 & -101 \\
\hline
\end{tabular}

Spectrophotometric studies

When cis-bis(malonato)diaquochromate(III) was taken and different amounts of sodium hydroxide were added, the solution retained its purple colour till the $\mathrm{pH}$ value reached to 6.00 . Beyond this $\mathrm{pH}$ the solution turned to different shade of green. Spectra of cis-bis(malonato)diaquochromate(III) $[0.004 \mathrm{M}]$ were recorded at different $\mathrm{pH}$ values by adding different quantities of $0.01 \mathrm{M} \mathrm{NaOH}$ solution. From Figure 4 it can be noted that at the lower $\mathrm{pH}$ values, the peak at shorter wavelength exhibits a bathochromic shift, but at higher $\mathrm{pH}$ values, small hypsochromic shift is noticed. The peak at longer wavelength exhibits a bathochromic shift with a decrease in the molar extinction coefficient value with increasing $\mathrm{pH}$. The molar extinction coefficient increases with increasing $\mathrm{pH}$ at shorter wavelength, but beyond $\mathrm{pH} 10.50$ the extinction coefficient value decreases. These observations indicate the gradual formation of the type $\mathrm{Cr}(\mathrm{mal})_{2}(\mathrm{OH})\left(\mathrm{H}_{2} \mathrm{O}\right)^{2-}$ and $\left.\mathrm{Cr}(\mathrm{mal})_{2}(\mathrm{OH})_{2}{ }^{3-} / \mathrm{or} \mathrm{Cr}(\mathrm{mal})(-\mathrm{mal})(\mathrm{OH})_{2}\right)\left(\mathrm{H}_{2} \mathrm{O}\right)^{3-}$.

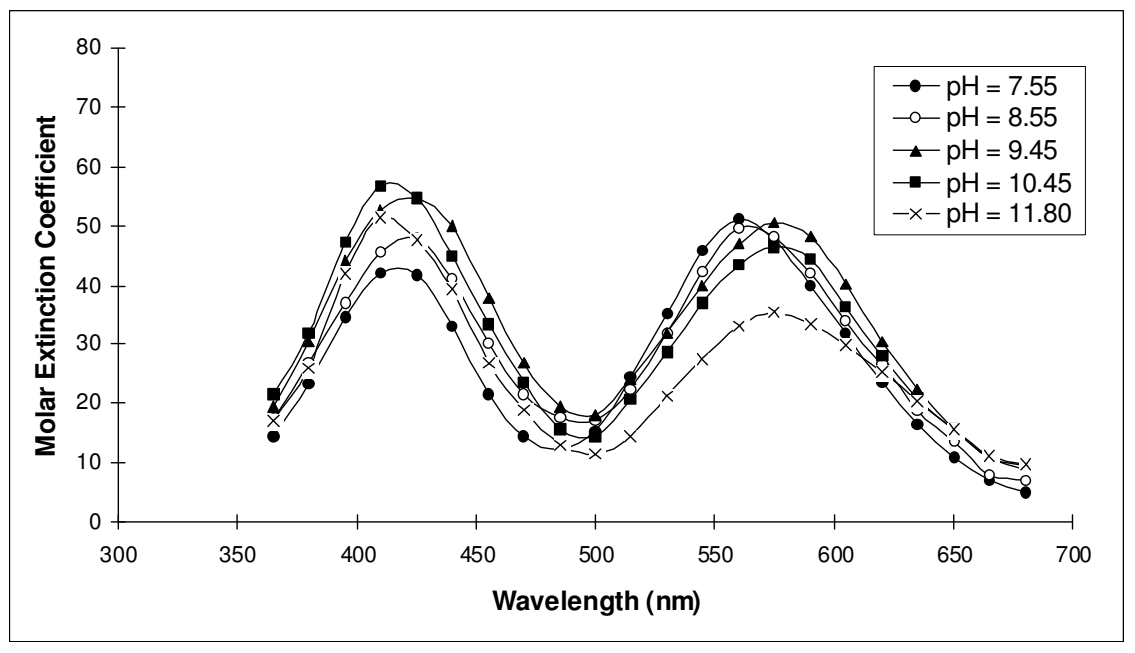

Figure 4. Absorption spectra of cis-bis(malonato)diaquochromate(III) at different $\mathrm{pH}$ values. $\left[\mathrm{Cr}(\mathrm{mal})_{2}\left(\mathrm{H}_{2} \mathrm{O}\right)_{2}{ }^{-}\right]=4.00 \times 10^{-3} \mathrm{M}$. 
In the octahedral substitution reactions, mainly two important effects operate viz, cis and trans effect. Under the experimental conditions, the cis effect operates in the $\mathrm{pH}$ range 5.40-6.80 and 7.40-8.80. On the other hand trans effect predominates at higher $\mathrm{pH}(>11.00)$. Under the experimental conditions the amino acids exists partly as Zwitter ion [30] and in an unprotonated form of the type, $\mathrm{AA}^{-}$. Based on the experimental observations the following mechanism is proposed for the substitution process in alkaline medium.

Proposed mechanism

Amino acid (AA) dependent path:

$$
\begin{aligned}
& \mathrm{Cr}(\mathrm{mal})_{2}\left(\mathrm{H}_{2} \mathrm{O}\right)(\mathrm{OH})^{2-}+\mathrm{OH}^{-} \stackrel{\mathrm{K}}{\rightleftharpoons} \mathrm{Cr}(\mathrm{mal})_{2}(\mathrm{OH})_{2}{ }^{3-}+\mathrm{H}_{2} \mathrm{O} \\
& \mathrm{Cr}(\mathrm{mal})_{2}(\mathrm{OH})_{2}^{3-}+\mathrm{AA}^{-} \underset{\text { Rate determining }}{\stackrel{\mathrm{k}_{1}}{\longrightarrow} \text { products }}
\end{aligned}
$$

Where AA`represents Amino Acid (Glycine / DL-alanine / DL-phenylalanine).

Amino acid (AA) independent path:

$$
\begin{gathered}
\mathrm{Cr}(\mathrm{mal})_{2}\left(\mathrm{H}_{2} \mathrm{O}\right)(\mathrm{OH})^{2-}+\mathrm{H}_{2} \mathrm{O} \underset{\text { Rate determining }}{\longrightarrow} \mathrm{\textrm {k } _ { 2 }} \\
\mathrm{Cr}(\mathrm{mal})(-\mathrm{mal})\left(\mathrm{H}_{2} \mathrm{O}\right)(\mathrm{OH})^{2-}+\mathrm{AA}^{-} \underset{\text { fast }}{\longrightarrow} \text { Products }
\end{gathered}
$$

where (-mal) represents single ended malonate (in ligand independent path a single ended malonate is envisaged [31]).

$$
\begin{array}{r}
\text { Rate }=\mathrm{k}_{1}\left[\mathrm{Cr}(\mathrm{mal})_{2}(\mathrm{OH})_{2}{ }^{3-}\right]\left[\mathrm{AA}^{-}\right]+\mathrm{k}_{2}\left[\mathrm{Cr}(\mathrm{mal})_{2}\left(\mathrm{H}_{2} \mathrm{O}\right)(\mathrm{OH})^{2-}\right] \\
\text { But } \mathrm{K}=\frac{\left\lfloor\mathrm{Cr}(\mathrm{mal})_{2}\left(\mathrm{CH}_{2}\right)_{2}^{3--}\right\rfloor}{\left[\mathrm{Cr}(\mathrm{mal})_{2}\left(\mathrm{H}_{2} \mathrm{O}\right)\left(\mathrm{CHI}^{2}\right)^{2-}\right]\left[\mathrm{OH}^{-}\right]}
\end{array}
$$

On substituting $\mathrm{K}\left[\mathrm{Cr}(\mathrm{mal})_{2}\left(\mathrm{H}_{2} \mathrm{O}\right)(\mathrm{OH})^{2-}\right]\left[\mathrm{OH}^{-}\right]$for $\left[\mathrm{Cr}(\mathrm{mal})_{2}(\mathrm{OH})_{2}{ }^{3-}\right]$ in equation (5)

Rate $=\mathrm{Kk}_{1}\left[\mathrm{Cr}(\mathrm{mal})_{2}\left(\mathrm{H}_{2} \mathrm{O}\right)(\mathrm{OH})^{2-}\right]\left[\mathrm{OH}^{-}\right]\left[\mathrm{AA}^{-}\right]+\mathrm{k}_{2}\left[\mathrm{Cr}(\mathrm{mal})_{2}\left(\mathrm{H}_{2} \mathrm{O}\right)(\mathrm{OH})^{2-}\right]$

$$
\frac{\text { Rate }}{\left[\mathrm{Cr}(\mathrm{mal})_{2}\left(\mathrm{H}_{2} \mathrm{O}\right)(\mathrm{OH})^{2-}\right]}=\mathrm{k}_{\mathrm{obs}}=\mathrm{K} \mathrm{k}_{1}\left[\mathrm{AA}^{-}\right]\left[\mathrm{OH}^{-}\right]+\mathrm{k}_{2}
$$

At fixed $\left[\mathrm{OH}^{-}\right]$, i.e. at a constant $\mathrm{pH}$ the equation transforms to

$$
\begin{aligned}
& \text { Rate }=\mathrm{K} \mathrm{k}_{1}{ }^{\prime}\left[\mathrm{AA}^{-}\right]+\mathrm{k}_{2} \quad \text { Here } \mathrm{k}^{\prime}{ }_{1}=\mathrm{k}_{1}\left[\mathrm{OH}^{-}\right] \\
& =\mathrm{k}^{\prime}\left[\mathrm{AA}^{-}\right]+\mathrm{k}^{\prime \prime}
\end{aligned}
$$

where $\mathrm{k}^{\prime}=\mathrm{Kk}^{\prime}{ }_{1}$ and $\mathrm{k}^{\prime \prime}=\mathrm{k}_{2}$ (for convenience $\mathrm{k}_{2}$ is represented as $\mathrm{k}^{\prime \prime}$ ). From the equation (8) it can be seen that when a plot of observed rate constant vs the concentration of the ligand is prepared at a constant $\mathrm{pH}$, the slope will be $\mathrm{k}^{\prime}$ and the intercept will be $\mathrm{k}$ ". 
Substitution reactions at Chromium(III) centers are inert and generally proceed by associative mechanism(A), interchange associative $\left(I_{a}\right), I_{d}$ and D-mechanism based on the experimental conditions. Substitution reactions at chromium(III) proceed by a hydrolysis pathway as well as direct substitution. As a result, two routes for these reactions are reported: ligand dependent and ligand independent routes. The $\mathrm{OH}$ group present in the substrate species in alkaline medium functions as a cis-activator facilitating substitution up to a $\mathrm{pH}$ of 8.80. There is a possibility that the $\mathrm{Cr}(\mathrm{III})$ species become unreactive and not eminable for substitution beyond this $\mathrm{pH}$. Hence, a mechanism is proposed where a single ended malonate species forms as an intermediate in the amino acid independent pathway. This is a clear example of a reaction proceeding by an $\mathrm{I}_{\mathrm{a}}$ and D-mechanism.

\section{REFERENCES}

1. Krishna Murthy, K.V.; Haris, G.M. Chem. Rev. 1961, 61, 213.

2. Ashley, K.R.; Hamm, R.E. Inorg. Chem. 1966, 5, 1645.

3. Kulprathi Panja, S.; Ashley, K.R. J. Inorg. Nucl. Chem. 1970, 32, 3565 .

4. Casula, M.; Illuminati, G.; Ortaggi, G. J. Inorg. Nucl. Chem. 1972, 11, 444.

5. Ashley, K.R.; Lamba, R.S. Inorg. Chem. 1974, 13, 2117.

6. Hamm, R.E. J. Am. Chem. Soc. 1953, 75, 609.

7. Banerjea, D.; Dutta Chaudhuri, S. J. Inorg. Nucl. Chem. 1968, 30, 871.

8. Khan, I.A.; Kabir-ud-Din J. Inorg. Nucl. Chem. 1981, 43, 1082.

9. Abdullah, M.A.; Barett, J.; Brien. P. J. Chem. Soc. Dalton Trans. 1984, 1647.

10. Subrahmanyam, D.; Anata Ramam, V. J. Indian Council Chemists 1997, 14, 40.

11. Ramasami, T.; Taylor, R.S.; Sykes, A.G. Inorg. Chem. 1976, 15, 2318.

12. Niogy, B.K.; De, G.S. Proc. Indian Acad. Sci. (Chem. Sci.) 1983, 92,153.

13. Niogy,B.K.; De, G.S. J.Indian Chem. Soc. 1984, 65, 389 .

14. Mitra, S.; De, K. Proc. Indian Acad. Sci. (Chem. Sci.) 1989, 101, 187

15. Mitra, S.; De, K. J. Indian Chem. Soc. 1990, 16, 67.

16. Shahid, M.; Khan, I.A.; Kabir-ud-Din J. Chem. Soc. Dalton Trans. 1990, 3007.

17. Kabir-ud-Din; Khan, I.A.; Sahid, M. Indian J. Chem. 1993, 32A, 171.

18. Kabir-ud-Din; Khan, G.J. J. Coord. Chem. 1992, 26,351.

19. Kabir-ud-Din; Khan, I.A.; Shahid, M. J. Indian Chem. Soc. 1992, 69, 864.

20. Khan, I.A.; Sahid, M.; Kabir-ud-Din Indian J. Chem. 1983, 22A, 382.

21. Khan, A.I.; Kabir-ud-Din Indian J. Chem. 1984, 23 A, 98.

22. Kabir-ud-Din; Khan, G.J. Ann. Chim. (Rome) 1985, 75, 279.

23. Kabir-ud-Din; Khan, G.J.; Khan, Z.; Rafiquee, Md.Z.A. J. Chem. Res. (S) 1996, 178.

24. Subba Rao, M.V.; Anantaramam, V.; Muralidhara Rao, V. Bull. Chem. Soc. Ethiop. 2009, 23, 197.

25. Subba Rao, M.V.; Anantaramam, V.; Muralidhara Rao, V. Asian J. Res. Chem. 2010, 3, 442.

26. Chang, J.C. J. Inorg. Nucl. Chem. 1968, 30, 945.

27. Olson, M.V.; Behnke, C.E. Inorg. Chem. 1974, 13, 1329.

28. Nageswarao, G.; Ananta Ramam, V.; Satyanarayana Rao, S.V.V.; Sambasiva Rao, R. J. Indian Chem. Soc. 1998, 75, 236.

29. Ananta Ramam, V.; Nageswara Rao, G.; Sambasiva Rao, R. Indian J. Chem. 1997, 36A, 964.

30. Voet, D.; Voet, J.G.; Biochemistry, John Wiley and Sons: New York; 1990; Chapter II, p 59.

31. Chang, J.C. Inorg. Nucl. Chem. Lett. 1969, 5, 587. 